\title{
A Research on the Role Played by Local and International Media into Conflict Management
}

\author{
Ibrahim T. I. Ukka*, Bienmali Kombate \\ School of Journalism and Information Communication, Huazhong University of Science and Technology, Wuhan, China \\ Email address: \\ ibrahimokah $a$ hust.edu.cn (I. T. I. Ukka), bienmali41@hust.edu.cn (B. Kombate) \\ ${ }^{*}$ Corresponding author
}

To cite this article:

Ibrahim T. I. Ukka, Bienmali Kombate. A Research on the Role Played by Local and International Media into Conflict Management. International Journal of Sustainable Development Research. Vol. 5, No. 4, 2019, pp. 98-105. doi: 10.11648/j.ijsdr.20190504.12

Received: April 6, 2019; Accepted: May 6, 2019; Published: December 25, 2019

\begin{abstract}
While several scholar had drew their study focusing on the role of media into conflict management, few have pay attention to the types, levels, and phases of the conflict. Looking to fulfill the research gap, this study aimed to investigate the effect of media into conflict management focusing on the level of media. Israel and Palestine conflict was use as a case study and to frame the analysis, the research data were collected through a series of questionnaires. As concluded by previous scholars, local media are a potential tool of deescalating in global conflict, in line with these literatures, our finding show that local media are source of peace building and conflict deescalating however international media interfere into conflict management according to their national interest and as an instrument of influencing foreign policy to the parties involve. We finally concluded that the current and future relationship and level of tension between Israel and Palestine could be predict by $\mathrm{Al}$ jazera.
\end{abstract}

Keywords: International Media, Local Media, Media Effect, Conflict, Israel, Palestine

\section{Introduction}

Media scholars and researchers, public opinions and viewpoints and observers have always accused both local and international media and journalists of having, at best; put oil on fire, at worst, fomenting the conflict. Regard to this issue, lack of studies have been undertake to seek to understand on how they affected through their report on the conflict management. The role of media in conflict management continues to evolve, as it requires a more comprehensive and general understanding of these aspects into conflict management. [1] Argued that understanding the impact of media reporting on conflict requires a new framework that captures the multilevel and hybrid media environments of contemporary conflicts. The role of media and the dynamics of geopolitical conflicts is a complicated and important problem. Media is also known as an independent actor that creates pressure for action on issues it deems necessary or justified. Therefore, it is important to develop this knowledge because of the dynamics of political and media conflicts, which are closely related, make different regions with consequences and opportunities. Unfortunately, when relevant experiments and research continue to develop and occur, the current view on the subject is still being planned. Therefore, this study consistently aims to research, identify and properly address the adverse impact at a comparative level between the local and international media because they result in many hindrances to that would help to known their impact at individual level.

This study offers a path towards that aim, by investigating in how the media in their report influence positively and negatively into conflict escalation. In this sense, the study approach provides the hybrid concept [1], which shows that different levels of media can be fluid and that their interaction also produces the results of the most important both top-down and bottom-up enterprises. [2] This study contributions are also part approach to understanding the interactions between local, and international media. [3] Also, the aim is to broaden the scope of media analysis through empirical research. In particular, we need to be aware of the "local" level of media studies, as media coverage of the conflict ultimately generates local conflicts and political dynamics, and because of the discrepancies that often exist 
between the level where the conflicts occur and how they are narrated throughout different media layers. This innovation should allow scholar and researchers, to better understand the complex relationships between the media (local and international media) and the conflict management, which should produce better theories and research.

\section{Previous Studies}

To understand objectively the nature and role of the media in conflict management, it is important to understand the different ways in which the media influences the management of conflicts and conflicts. [4] Argued that most academics and researchers have focused on the role of the media in economic, social and political issues that affect states and pay little attention to conflict. In addition, the impact of the media on conflict management is an emerging field that has been studied due to the lack of multi-disciplinary models and concepts to examine the role of media in a conflict perspective.

The overall statistical summary of armed political conflicts provides a basic understanding of the current situation in terms of destruction, loss of life and suffering. Several researchers have pointed out that globalization has brought about important qualitative changes in the goals and dynamics of violent conflict. Some, like Kaldor [5], argue that it was the information technology revolution of the 1980s and 1990s that led to a particular type of globalization, which led to the need to redefine what we consider. As means and conflicts.

Even if the media can give us the intensity of the violence, the place where they fight, why, how and who fights, the main problem of the influence of the media on the populations, which ultimately determines the orientation of the media. Ways. Conflict, it was not determined. Most violent conflicts are asymmetrical and occur mainly within state boundaries. What is important to emphasize, especially with regard to the role of the media, is to win the "heart and mind" of people. Since a state is almost always militarily superior, non-state actors are more dependent on psychological warfare, which implies influencing the attitudes and perceptions of a population, for example, through the media [6]. As a result, the media dimension has become increasingly important and it is no coincidence that media assistance has emerged and gained importance since the end of the Cold War.

The media has a very complex role to play, which, unfortunately, is often taken for granted by policy makers and the military. Decision-makers often claim that statements affirming the impressive effects of the media are heard. Politicians, and even researchers, often assume the effect of the media in political conflicts. A 1995 study shows that $64 \%$ of US officers are still convinced that the media is the main cause of the ruin of the Vietnam war effort [7]. In these circumstances, it is surprising, and perhaps even alarming, that relatively little research and resources have been devoted to a better understanding of the role of the media in armed conflict and the democratization of states [7].

The recent acceleration of democratization is another aspect that has important consequences for the media in violent conflicts. This began before the end of the cold war, but since then a "fourth wave" of democratization has begun [8]. The democratizing states are participating in a complex process of rehabilitating traditional political structures and attempting to integrate democratic institutions and norms. The integration of independent, responsible and pluralistic media at the editorial and economic level is essential for democratization. Political changes often stimulate hope and offer unique opportunities for different groups in society, often previously marginalized, to influence political dynamics, while those who control power may have difficulty accepting or not being conceivable [8]. In such a situation, the media could play an invisible role in the division of groups of society in terms of social status. Discrimination against the marginalized, led by the political elite, could provide the media with an appropriate motive for creating and reinforcing the triggers and triggers of the conflict by using "oppositional metaphors" ("us" as opposed to "them"). [9]. However, this indirect influence of the media on conflicts has not been sufficiently emphasized.

\subsection{International Media and Internal Conflict}

In the media landscape, the international media's "information war" precedes "war information" and even encourages the "war communication" mode that several scholar have attempted to analyze,. It results from the modalities of competition between the media, especially television channels when covering a war. For example in the handling of the Iraq crisis by the Bush Administration, this is what it was about: communicating in order to convince the world, "friends" and "enemies", of its desire to arrive on D-Day at the end announced the war against Iraq [10]. In our view, there is no doubt that the Bush administration's communication during this Iraq crisis was already a "war communication". Certainly, by nature, the crisis is a natural tropism for the mass media. From experience, it generates an increased audience while reemerging dubious modes of communication such as rumor, forgery or ideological intoxication, undermining the activity of the information professionals who are journalists as well as those of the media responsible for public communication, including the rulers. We have seen in recent conflicts in Bosnia, Rwanda, Serbia, Kosovo, Ivory Coast, Iraq and elsewhere, how "hatred" can be a driving force for communication strategies and to present oneself under appearances of good form or good tone [11].

Insofar as recent history proves that media competition is gaining momentum in international conflicts and highlighting the international media, it reveals a new "information crisis" that is not just the result of crisis ". In the context of the "war in Iraq" and its aftermath, war communication has avoided too much disruption of the media system. This would have presented a risk to the very credibility of the actors in power, the media and the 
democratic regime as well. In the context of the evolution of known media practices, a military intervention cannot drag on even if the political power so wishes. A fortiori when time does not have the same meaning as yesterday, in the era of permanent, real or possible.

In terms of mediated communication within a democratic regime, one cannot remain in a monocular or unilateral approach to conflicts or major crises. International pressure, with its interplay of relations between States and economic actors, is a reality that also leads the international media to open the horizons and to consider the problems in all their dimensions and in all their extensions by sensitizing or challenging public opinion. In the absence of debates, the major risk is that of a diversion of democracy for the sole purpose of the supporters of political power, or even their collusion with the key economic and media actors.

Usually, international media take part in conflict management when in most situations of increasing tension or when the conflict reaches the threshold of violence, [12]. As a study added that usually it is after a precipitating event, such as a "refugee exodus or a massacre", that is sufficiently photogenic and dramatic enough that push international media to report[13] .

Once the international media has expressed interest in a conflict, unfortunately, the critical moment of prevention usually ends. Without denying, international media are an important part of mass media consumption in terms of information on conflict situation. For example in Ivory coast civil war, during the single party until the coup of December 1999 , it was the foreign press, newspapers, radio and television that spread the information [14-15]. It is also common to find in the local media "copy-pasting" of articles from the foreign press and transcripts of statements taken from Western radio or television. Thus, foreign and international media, albeit with a small audience, are considered alternative media. Decades of political monopartism have given those international media such as France 24, RFI, CNN, Al Jazeera, New York Times, Russia Today, CCTV and others the status of an information authority for both readers and journalists. Currently, the old alternative media are under suspicion and are accused, especially in the favoring people of playing the enemy's game. This brief overview of the media landscape reveals the tensions and contradictions that characterize the situation of the media and their actors, which are part of a logic of political confrontation. Voluntarily or not, newspapers are often linked to political interests that are necessarily partisan. Indeed, newspapers are seen as instruments of conquest and conservation of political power [16].

International media can easily capture the world's attention regarding the conflict through their report. As they occupy a prominent place in daily life, especially in developing countries, they are therefore able to spread conflicts over the world. These days in most armed conflicts, governmental and non-territorial reasons; Parties often worry about making sure that people are "on their side", which can distort the facts and try to control the flow of information. For the same reason, the intervention of free and impartial global media is important not only for the global public, but also for those directly affected. However, there still a small number of conflicts that receive the attention of the international media.

\subsection{Local Media and Conflict}

In an internal or international conflict, it always noted that local media play a crucial role in the conflict management. However, local media intervention in an international conflicts is usually serve for commercial interests, for example the Australian report during the conflict of the Democratic Republic [17]. Local media can also joined the flag of patriotism or report in the interests of the nation, for example the British media during the Falklands war in 1982 [18]. But, local media can report international conflicts to strengthen certain local agendas and reactivity based on ideological claims, for example when Dutch media presented stereotypical reports about the war in Bosnia and proposals for the Dutch government [19]. Local media can also be involved in international conflicts to protest the interests of geopolitics and ideological values that determine their existence and function. In other words, local media can only report internal or international conflicts through ethical responsibility to attract the attention of local audiences to the national or international crisis, for example the British Daily Mirror part of the invasion of Iraq by the United States [18].

\subsubsection{Local Media and Internal Conflict}

Local media play the essential role during the conflict [20]. Bequeath the information through community radios in different language can help reach people from different regions and different domination more easily. Thus, citizens of the country involve in the conflict can be reached directly and their experiences and personal lives can be integrated much better compare to international media. However, the danger of political manipulating and igniting ethnic tensions cannot be ignored.

Usually in civil or armed conflict, local media including radio and $\mathrm{TV}$ in their report used to convey messages of peace to combatants and refugees visiting border areas [20]. As the structures of democratic impose the need of the society actively participates in the creation and dissemination of content [21]

Local media are deem to have a deeper knowledge of the existing political issues, the background of the participants in the conflict, and the changes that preceded the onset of violence. We all know that conflicts do not occur spontaneously but tend to have a history. Local media might not only tend to influence the society before the conflict by recognizing and treating the problem correctly, but also afterwards. Unlike international media that cover conflict, local media are recognized as part of the society with the ability to accelerate and amplify fears or reduce them. However, we may not ignore that journalism can play a role in conflict escalating, which also demonstrates the potential 
for positive goals. The media has the power to calm tensions before they reach a critical point and to keep a critical eye on the government, the opposition and society. By providing reliable information and reaching a wide audience, the media helps to manage conflict and promote democratic principles. After conflict, reconciliation and development of society can also be encouraged [22].

\subsubsection{Local Media and International Conflict}

The information given by local media in an internal conflict is usually different when in an international conflicts. According to a study [23], to understand the phenomenon of inter group interaction within the period of international conflict, we needs to integrate various layers of analysis. Local media in international crisis are the vehicle for political processes. Hass [24], added that local media are the canal that transmitting the message between politics and citizens. Although the importance of local media in conflict is recognized [25], it is clear that [26], observations confirm that "many scholar pay more attention on the role of international media in conflict. In addition, few studies which have been conducted on the role of local media in attracting media attention in international crisis.

We all notice that in case of clashes between parties, the parties shall communicate with each other, not between themselves, but as private members. International connotation is a societal feature of conflict [27]. In addition, international conflicts claim to be politically based on citizenship and not on ethnic groups, male or female. [28] Argue that citizenship occurs when someone "participates in the struggle of his group to know that it is the most connected society". For example, the Scarborough Shoal crisis captures the identity of China or the Philippines, as well as China and the Philippines, and in the context of the Shaal Scarborough conflict, the people who describe each one of them. Countries refer to other Chinese and Filipino, as groups or as a possible group of people.

The construction of nationalism by the local media during the international conflict should not be used striking national symbols of loyalty such as flags, national anthems, or call for mass compliance with political leaders, [29]. However, local media were strategically established to create a common mind not only because of the rapid in spreading information, but more often because the public tends to believe that information from media sources is a social reality rather than a subjective version of the media as an intrinsic reality [30]. These communication strategies will become nationalist bias and undermines the perceived credibility of the media as the bearer of the truth. Maintaining the power of the media to build internal symbolic representations in the public space, reports must remain objective as easily as possible. However, the media can build loyalty to one's country more subtly [31-32]. Mores gave birth to what is commonly called superficial techniques. Nationalism [33].

Media has the power to show opinions from people who share different views point [34]. Social strength begins with the ability to change social reality and come to many perspectives [30]. To understand media discussions, the information should be shown not just as smuggling, but also as a link between state and politics, that plays an important role in society. [30]. Within the period of an international crisis, "media especially local media stand as a political vehicle, locate between politics and citizens"[35].

The national identity of local media is not just association with groups of State members, or groups outside the competing state, but also campaigns in other countries who are likely to be involved in regional conflicts. Thus, in the context of international crisis, each local media target the local audience. For example in the study of the role of Chinese and Philippine local media during the Scarborough Shoal conflict, [29] found that there were two contradictory and nationalistic versions regarding this international conflict constructed by local media of the two countries. [36] Nevertheless, on the far side the politicization of local media audiences to save their country at a any cost, the Chinese and Filipino media can also create reporting styles for third-party viewers for example, the United States may be involved in regional conflicts as third party international [37].

\section{Methodology}

To analyze the role of media both international and local in conflict management in this paper, we opted for exploratory research design which is commonly perceived as information retrieval tool for processing of one or more information within a complex document environment, in order to answer a question or solve a problem [38-39]. But, the need for information will be filled through research, sorting, reading and understanding knowledge-based documents [40-41]. The functioning of this paradigm was closely related to the idea that it was sufficient to formulate a survey questionnaires which leading to extract the information in adequacy with the need [42].

The international and geopolitical conflict that opposes Israel and Palestine was use as a case study in this paper. As argued by the media scholar [43], "the Israeli-Palestinian conflict is the most international conflict treated by media". Meanwhile, this statement seem true, the question still if the quantity of media report matter more? Our approach in this study focused the intention on how the media coverage influence the conflict itself and more highlighted on the level of media (international and local) aspects.

To frame the analysis, the researchers collected date through survey questionnaires, which was divided, into two series of questionnaires. The first part designed to collect data regarding the role of local media into international conflict management, and in the second part the respondents was asked to answer regarding the role-play by international media into international conflict management. The population of this study were media practitioners in Israel and Palestine and the convenient sampling method was use in selecting the respondents. 


\section{Finding and Discussion}

\subsection{Research Results on the Role of Local Media in Conflict Management}

The first part of the survey questionnaires sought to know the study background and career experience in media industry of the respondents (media practitioners).

Table 1. Respondents study background and career experience.

\begin{tabular}{|c|c|c|c|}
\hline Elements & & no & $\%$ \\
\hline \multirow{4}{*}{ How long have you served in the media industry } & 1 to 12 months & 18 & 8.7 \\
\hline & 2 to 5 years & 72 & 35 \\
\hline & 6 to 9 years & 39 & 18.9 \\
\hline & 10 and over & 77 & 37.4 \\
\hline \multirow{5}{*}{ What is your level of education? } & High School & 9 & 4.4 \\
\hline & Tertiary College & 7 & 3.4 \\
\hline & University Education & 150 & 72.8 \\
\hline & Graduate School & 30 & 14.6 \\
\hline & others & 10 & 4.9 \\
\hline \multirow{3}{*}{ Do you have any formal training in Journalism } & Yes & 161 & 78.2 \\
\hline & No & 45 & 21.8 \\
\hline & Certificate level & 59 & 28.6 \\
\hline \multirow{3}{*}{ If yes to question 2 above, what level of Journalism training do you have } & Diploma Level & 25 & 12.1 \\
\hline & Degree Level & 46 & 22.3 \\
\hline & Post Graduate Level & 31 & 15 \\
\hline \multirow{4}{*}{ In your opinion, how would you rate the relationship between Israel and Palestine? } & Peaceful & 11 & 5.3 \\
\hline & Average & 23 & 11.3 \\
\hline & Violent & 166 & 80.6 \\
\hline & Extremely Violent & 6 & 2.9 \\
\hline
\end{tabular}

Source: Field data 2019.

The results in table 1 showed that among the 206 local media practitioners in Israel and Palestine interviewees, 56.3\% were old in the industry with career above 5 years of work experience and a considerable amount of $35 \%$ of the respondents have their work experience between 2 to 5 years which is somehow acceptable to hold a professional experience in the field. But, $8.7 \%$ or 18 out of 206 respondents were new in the industry.

To know the level of education, the respondents were asked, "What is your level of education" and $72.8 \%$ answered having their university first degree, $14.6 \%$ have master and $\mathrm{PhD}$ degree and $3.4 \%$ have graduated from
Tertiary College. Only $4.4 \%$ are graduated from High School. However, among the 206 media practitioners interviewed, only $78.2 \%$ have a formal training in media accredited school in both Israel and Palestine and among them, 28.6\% have Certificate level, 12.1\% Diploma Level, 22.3\% Degree Level and 15\% Post Graduate Level.

To know the viewpoints of our respondents regarding the relationship of Israel and Palestine, the question "In your opinion, how would you rate the relationship between Israel and Palestine"? In addition, more that $80 \%$ or 172 out of 206 rated violent and extremely violent. Only $5.3 \%$ or 11 out of 206 rated peaceful and $11.3 \%$ rated average.

Table 2. Respondent Perception on the role of local media into international conflict.

\begin{tabular}{|c|c|c|c|c|c|c|c|c|c|c|}
\hline \multirow{2}{*}{ Statement } & \multicolumn{2}{|c|}{ Strongly Disagree } & \multicolumn{2}{|c|}{ Disagree } & \multicolumn{2}{|c|}{ Neutral } & \multicolumn{2}{|c|}{ Agree } & \multicolumn{2}{|c|}{ Strongly Agree } \\
\hline & no & $\%$ & no & $\%$ & no & $\%$ & no & $\%$ & no & $\%$ \\
\hline $\begin{array}{l}\text { Each media station have a written station } \\
\text { policy that controls programme content }\end{array}$ & 46 & 22.3 & 61 & 29.6 & 46 & 22.3 & 35 & 17 & 18 & 8.8 \\
\hline $\begin{array}{l}\text { Media (broadcast or print) is the root cause } \\
\text { of this conflict }\end{array}$ & 63 & 30.5 & 70 & 34 & 53 & 25.7 & 14 & 6.8 & 6 & 2.9 \\
\hline $\begin{array}{l}\text { Media did not play a significant role in } \\
\text { highlighting key issues related to Israeli - } \\
\text { Palestinian conflict }\end{array}$ & 28 & 13.6 & 67 & 32.5 & 53 & 25.7 & 49 & 23.8 & 9 & 4.4 \\
\hline $\begin{array}{l}\text { Local media are not playing an active role } \\
\text { to avert the Israeli - Palestinian conflict }\end{array}$ & 26 & 12.6 & 68 & 33 & 60 & 29.1 & 37 & 18 & 15 & 7.3 \\
\hline $\begin{array}{l}\text { Local media are not promoting democracy } \\
\text { and peace initiatives as the priority in } \\
\text { coverage the issue deserved. }\end{array}$ & 29 & 14.1 & 58 & 28.2 & 74 & 35.9 & 34 & 16.5 & 11 & 5.3 \\
\hline
\end{tabular}

Source: Field data 2019.

The table 2 summarize the local media practitioner viewpoint on the role of local media into international conflict management. To the first question "Each media station have a written station policy that controls programme content" the 
majority of the respondents 107 out of 206 rated disagree and strongly disagree and $25.8 \%$ rated agree and strongly agree which confirm that most of the local media doesn't have internal rule that regulate the program content. However, $64.5 \%$ disagree with the statement that "Media (broadcast or print) is the root cause of this conflict" against $9.7 \%$ who rated agree and strongly agree. This show that, meanwhile the local media station are not well organize, they are far away to cause conflict.

$46.1 \%$ of the respondents agree that local media play a significant role in highlighting key issues related to Israeli Palestinian conflict against $28.2 \%$. In addition, $45.6 \%$ agree that Local media are playing an active role to avert the Israeli Palestinian conflict against $25.5 \%$. Looking to know how local media influence the public in promoting democracy and peace building, $42.3 \%$ of the participants are persuaded that local media are promoting democracy and peace initiatives as the priority in coverage the issue deserved against $21.8 \%$. These three questions were asked to seek if local media in their framing and agenda setting fuel the international conflict that oppose the two Nations [44]. The finding show that local media play the role of peace building and conflict resolution supporting the Finding who argued that Local media are sensitive to the task of promoting tolerant and diverse perspectives, which can be informative and entertaining and have a broad audience potential. Local media in international conflict that oppose countries usually play a significant role in creating and furthering both facilitating factors and triggering factors, [45-46].

\subsection{Research Results on the Role of International Media in Conflict Management}

Table 3. International media user background.

\begin{tabular}{llll}
\hline Elements & & no & \% \\
\hline \multirow{2}{*}{ Position } & Journalist & 228 & 90.8 \\
& others & 23 & 9.2 \\
Type of Media & Online Journalism & 172 & 68.5 \\
& Radio & 60 & 23.9 \\
& TV & 19 & 7.6 \\
Media Use & BBC & 15 & 6 \\
& CNN & 4 & 1.6 \\
& Al jazera & 162 & 64.5 \\
& China Daily & 4 & 1.6 \\
& others & 66 & 26.3 \\
\hline
\end{tabular}

Source: Data field 2019.

To avoid any bias in the research, the questionnaires aiming to sough the role of international media in a conflict were also sent to the individual with profession as journalism or related. As shown in table $3,90.8 \%$ or 228 out of 251 were journalists. The majority or $68.5 \%$ of the international media user access the information through online journalism. Only $23.9 \%$ use radio and $7.6 \%$ through TV news and broadcasting. Among the interviewees, the amount of $64.5 \%$ or 162 out of 251 international media users use $\mathrm{Al}$ jazera, $6 \%$ use $\mathrm{BBC}, 1.6 \%$ use CNN, 1.6 China Daily News, and 26.3\% for others.

Table 4. Participant Perception on the Role of International Media into Conflict Management.

\begin{tabular}{|c|c|c|c|c|c|c|c|c|c|c|}
\hline \multirow{2}{*}{ Statements } & \multicolumn{2}{|c|}{ Strongly Disagree } & \multicolumn{2}{|c|}{ Disagree } & \multicolumn{2}{|c|}{ Neutral } & \multicolumn{2}{|c|}{ Agree } & \multicolumn{2}{|c|}{ Strongly Agree } \\
\hline & no & $\%$ & no & $\%$ & no & $\%$ & no & $\%$ & no & $\%$ \\
\hline $\begin{array}{l}\text { International Media in Israeli-Palestinian conflict } \\
\text { play the role of "negotiation with actors" }\end{array}$ & 33 & 13.1 & 95 & 37.8 & 66 & 26.3 & 47 & 18.7 & 10 & 4 \\
\hline $\begin{array}{l}\text { International Media in Israeli-Palestinian conflict } \\
\text { play the role of Mass education }\end{array}$ & 34 & 13.5 & 92 & 36.7 & 75 & 29.9 & 50 & 19.9 & 0 & 0 \\
\hline $\begin{array}{l}\text { International Media in Israeli-Palestinian conflict } \\
\text { are Applying high journalistic standards }\end{array}$ & 80 & 31.9 & 106 & 42.2 & 41 & 16.3 & 20 & 8 & 4 & 1.6 \\
\hline
\end{tabular}

Source: Data field 2019

Table 4 summarize the research quest on the role of international media into conflict management. On the 251 participants in this study, only $22.7 \%$ supports the statement that International Media play the role of "negotiation with actors" in a conflict and $49.8 \%$ disagree with the statement, but, $50.2 \%$ of the interviewees confirmed that International Media doesn't play the role of Mass education in a conflict against $19.9 \%$. However, $74.1 \%$ of the participants supports that International Media not applying high journalistic standards" in the conflict management against $9.6 \%$. In line with it, on the statement "International Media in Israeli-Palestinian conflict Cause Conflict in Stereotyping", 104 out of 251 agree and 91 out of 251 interviewees rated disagree.

\section{Conclusion}

The research finding showed that International media are faraway in playing the role of mass education, Negotiation, either applying high journalistic standards. In line with our finding, previous studies [47-54], all concluded their studies that International media such $\mathrm{CNN}, \mathrm{BBC}, \mathrm{Al}$ jazera and others actors intervene in conflict management according to their national interest, lack of certainty policy, and various factors including humanitarian reaction.

More ever, the results shown in table 3, the current and the future of Israel - Palestine conflict and peace building could be shape by Al jazera (more that $64.5 \%$ of the population international media users use $\mathrm{Al}$ jazera). This finding come in support who concluded that The battle of hearts and minds 
in the Middle East did not take place in the streets of Baghdad, but in the events and news of Al Jazeera, The future of China was not developed by the Communist Party bureaucrats, but by bloggers who worked quietly in the cybercafé [55]. The latest al-Qaeda attack will not take place at Osama bin Laden's funeral, but in cells around the world connected via the Internet.

Al Jazeera intervention in Israel-Palestine conflict reflect it effect in influencing foreign policy and apply pressure on the parties involved in the conflict to address the issues.[56], argued that meanwhile international media can enhance mutual understanding among the parties involve; they can be the root cause of conflict and misunderstanding.

\section{References}

[1] P. Robinson, "Moving media and conflict studies beyond the CNN effect Eytan Gilboa Maria Gabrielsen Jumbert Jason Miklian," vol. 42, no. 0134, pp. 654-672, 2016.

[2] Gilboa, "Media Coverage of International Negotiation: A Taxonomy of Levels and Effects," Int. Negot., vol. 5, no. 3, pp. 543-568, 2003.

[3] G. Helmke and S. Levitsky, "Helmke, Levidsky (2004) Informal institutions and comparative ploitics; a research agenda," vol. 2, no. 4, 2004.

[4] C. Newbold, "Approaches to cultural hegemony within cultural studies," Approaches to Media A Reader. London Edward Arnold, 1995

[5] F. Armao, M. Randall-Schab, A. T. Leverton, K. E. B. von Wittelsbach, and E. B. Pisani, "Inside war: Understanding the evolution of organised violence in the global era," Insid. War Underst. Evol. Organised Violence Glob. Era, no. January, pp. $1-206,2015$

[6] B. S. Himelfarb and M. Chabalowski, "Medi, Conflict Prevention and Peacebuilding :," pp. 1-5, 2008.

[7] J. Wiley and M. Junei, "Global Communications, International Affairs, and the Media since 1945 by Philip M. Taylor Review by: Eliot A. Cohen Published by: Council on Foreign Relations Stable URL: http://www.jstor.org/stable/20048909. Your use of the JSTOR archive indicat," vol. 77, no. 3, pp. 137-138, 2014

[8] R. S. Greenberger, "Dateline Capitol Hill: The New Majority's Foreign Policy," Foreign Policy, vol. 101, no. 101, p. 159, 2006.

[9] T. A. Van Dijk, News analysis: Case studies of international and national news in the press. Routledge, 2013.

[10] J. Habermas, "Political communication in media society: Does democracy still enjoy an epistemic dimension? The impact of normative theory on empirical research," Commun. Theory, vol 16, no. 4, pp. 411-426, 2006.

[11] S. Kendzior, "A Reporter Without Borders," Probl. Post-Communism, vol. 57, no. 1, pp. 40-50, 2010

[12] R. O. Mensah and A. Acquah, "Assessing the Role of the Mass Media to Conflict Resolution in Tuabodom Assessing the Role of the Mass Media to Conflict Resolution in Tuabodom," no.
October, pp. 0-5, 2017.

[13] J. C. Menaut, J. Gignoux, C. Prado, and J. Clobert, "Tree community dynamics in a humid savanna of the Cote-d'Ivoire: modelling the effects of fire and competition with grass and neighbours," J. Biogeogr., pp. 471-481, 1990.

[14] H. Koné, "La dynamique des medias dans les societes en mutation. Le cas de la cote d'ivoire." Strasbourg 1, 1989.

[15] M. Pierre, D. D. Sébastien, K. Mathias, and M. A. Franck, "Control of the cholinesterases of the pesticides applicators in Abidjan (Côte d'Ivoire)," Eur. J. Sci. Res., vol. 39, no. 2, pp. $176-182,2010$

[16] P. D. Arpa, "Government und the Press What Partnership for Good Gove ranee in Nigeria' Government And The Press : What Partnership For Good Governance In Government And The Press: What Partnership For Good Governance In Nigeria ?," no. January 2012, 2016.

[17] V. Hawkins, "National interest or business interest: Coverage of conflict in the Democratic Republic of Congo in The Australian newspaper," Media, War Confl., vol. 2, no. 1, pp. 67-84, 2009.

[18] P. Goddard, P. Robinson, and K. Parry, "Patriotism meets plurality: reporting the 2003 Iraq War in the British press," Media, War Confl., vol. 1, no. 1, pp. 9-30, 2008.

[19] M. Gibbert, "W Hat P Asses a S a R Igorous C Ase S Tudy?," vol. 29 , no. 13 , pp. $1465-1474,2008$.

[20] M. Elfadil and Y. Suliman, "Introduction to Space Science and Solar Cells This pdf circulated in A workshop on Introduction to Space Science and Solar Cells," vol. 6, no. 036, 2014.

[21] M. Jobbins and F. Ahitungiye, "Peacebuilding and Conflict Prevention in Burundi's 2015 Election Crisis," Glob. Summitry, vol. 1, no. 2, pp. 205-218, 2016.

[22] G. Fischer, "Full-Text," Context. Syst. 'Right' Information, 'Right' Time, 'Right' Place, 'Right' Way, to 'Right' Pers., 2012.

[23] T. M. Singelis, M. H. Bond, W. F. Sharkey, and C. S. Y. Lai, "Unpackaging culture's influence on self-esteem and embarrassability: The role of self-construals," J. Cross. Cult. Psychol., vol. 30, no. 3, pp. 315-341, 1999.

[24] H. Gardner and N. Plant, "Oxygen Radical Chemistry p. 78," no. March, 2016.

[25] F. International, M. Support, B. A. Puddephatt, and I. M. Support, "Conflict and the role of the media," Conflict, no. April, 2006.

[26] V. Blondel, A. Gajardo, M. Heymans, P. Senellart, and P. Van Dooren, "A measure of similarity between graph vertices," 2004.

[27] B. P. Carlin and T. A. Louis, Bayesian methods for data analysis. CRC Press, 2008.

[28] N. Nadeem, "Identity and leadership in virtual communities: establishing credibility and influence," Choice Rev. Online, vol. 51, no. 11, pp. 51-6217-51-6217, 2014.

[29] P. M. Elliott, "2014 ESC guidelines on diagnosis and management of hypertrophic cardiomyopathy," Russ. J. Cardiol., vol. 121, no. 5, pp. 7-57, 2015. 
[30] P. Lunt and S. Livingstone, "Language and the media: An emerging field for social psychology Book section," new Handb. Lang. Soc. Psychol., pp. 585-600, 2001.

[31] G. Li, Y. Wu, and K. Gao, "Effects of typhoon Kaemi on coastal phytoplankton assemblages in the South China Sea, with special reference to the effects of solar UV radiation," $J$. Geophys. Res. Biogeosciences, vol. 114, no. 4, 2009.

[32] L. Tsaliki, "The Media and the Construction of an "Imagined Community': The Role of Media Events on Greek Television," Eur. J. Commun., vol. 10, no. 3, pp. 345-370, 1995.

[33] M. Billig, Banal nationalism. sage, 1995.

[34] M. J. Pitts and J. F. Nussbaum, "Integrating the past and paving the future: Examining current trends and extending boundaries of language and social psychology research," J. Lang. Soc. Psychol., vol. 25, no. 3, pp. 197-202, 2006.

[35] R. Hass, "Rejuvenation in distinct cell populations - What does it mean?," Exp. Gerontol., vol. 44, no. 10, pp. 634-638, 2009.

[36] A. Bell, "Language Style as Audience Design Author ( s ): Allan Bell Published by: Cambridge University Press Stable URL : http://www.jstor.org/stable/4167516," vol. 13, no. 2, pp. 145-204, 1984

[37] B. Simon and C. Kiel, "Simon Klandermans," pp. 319-331, 2001.

[38] B. Kombate, "Extra-Financial Analysis of IFRS Adoption and Application in Developing Country: the Case of Indonesia." Universitas Sebelas Maret, 2017.

[39] F. Papy and S. Chauvin, "Users and librarians: communities dissociated by practice to bring closer by interest."

[40] A. C. Gunther, "Biased Press or Biased Public? Attitudes Toward Media Coverage of Social Groups," Public Opin. Q., vol. 56, no. 2 , p. $147,1992$.

[41] L. Schamber and G. Marchionini, "Information Seeking in Electronic Environments," J. Educ. Libr. Inf. Sci., vol. 37, no. 1, p. $81,2010$.

[42] M. J. Bates, "The design of browsing and berrypicking techniques for the online search interface," Online Rev., vol. 13, no. 5, pp. 407-424, 1989.

[43] A. Abunimah, One country: A bold proposal to end the Israeli-Palestinian impasse. Macmillan, 2006.

[44] J. H. F. Botes, D. J. Bosch, and L. K. Oosthuizen, "A simulation and optimization approach for evaluating irrigation information,” Agric. Syst., vol. 51, no. 2, pp. 165-183, 1996.

[45] S. Jäger and J. Link, Die vierte gewalt. 1993.

[46] T. A. Van Dijk, Discourse as social interaction, vol. 2. Sage, 1997.

[47] E. Gowing et al., "Chemical characterization of $\mathrm{A} \beta$ 17-42 peptide, a component of diffuse amyloid deposits of Alzheimer disease," J. Biol. Chem., vol. 269, no. 15, pp. 10987-10990, 1994.

[48] M. Shaw and D. Garlan, Software architecture, vol. 101. prentice Hall Englewood Cliffs, 1996.

[49] M. A. C. Perryman et al., "The Hyades: distance, structure, dynamics, and age," arXiv Prepr. astro-ph/9707253, 1997.

[50] L. Minear, C. Scott, and T. G. Weiss, The news media, civil war, and humanitarian action. Lynne Rienner Publishers, 1996.

[51] Gandini and M. N. Belgacem, "Furans in polymer chemistry," Prog. Polym. Sci., vol. 22, no. 6, pp. 1203-1379, 1997.

[52] R. A. Robinson and R. H. Stokes, Electrolyte solutions. Courier Corporation, 2002.

[53] J. Dannull et al., "Enhancement of vaccine-mediated antitumor immunity in cancer patients after depletion of regulatory $\mathrm{T}$ cells," J. Clin. Invest., vol. 115, no. 12, pp. 3623-3633, 2005.

[54] D. Oyserman, M. Kemmelmeier, and H. M. Coon, "Cultural psychology, a new look: Reply to Bond (2002), Fiske (2002), Kitayama (2002), and Miller (2002).," 2002.

[55] P. Seib, The Al Jazeera effect: How the new global media are reshaping world politics. Potomac Books, Inc., 2008.

[56] M. E. Zingarelli, "The CNN effect and the Al Jazeera effect in global politics and society." Georgetown University, 2010. 